\title{
Prototipe smart home berbasis mikrokontroler arduino dan smart phone
}

\author{
Mafruddin $^{1^{\star}}$, Sulis Dri Handono², Avin Darma Irawan ${ }^{3}$ \\ 1,2 JurusanTeknik Mesin, Fakultas Teknik, Universitas Muhammadiyah Metro \\ ${ }^{3}$ Prodi Teknik Mesin, Fakultas Teknik, Universitas Muhammadiyah Metro \\ Jl. Ki Hajar Dewantara 15 A Kota Metro, Lampung, Indonesia \\ *Corresponding author: mafruddin.mawon@yahoo.com
}

\begin{abstract}
In this study, a home electrical control system and electronic components were designed using an Arduino Uno R3 microcontroller equipped with a motion sensor and connected to a Bluetooth module and a GSM (Global System for Mobile Communications) SIM (Subscriber Identification Module) module. In addition, the Smart Home prototype will also be equipped with earthquake detection sensors, fire sensors and sensors as soon as possible to deal with early earthquakes and fire detection. The purpose of research is to see the performance of the smart home system. The research method used is a research method with methods and making and testing Smart home prototypes. Testing is done by running the system to see the performance of the system being made. From the research results it can be ignored that the electrical control system and electronic components made using the Arduino Uno R3 microcontroller and the Bluetooth module and the GSM SIM module can work properly, the electrical system and electronic components can be turned on and off using a GSM SIM and Bluetooth module. The security system uses motion sensors and a GSM SIM module to work properly, the system can send SMS (Short Message Service) notifications to homeowners if human movement. The earthquake and fire detection sensor system in the smart home prototype can work properly, the system can turn on notification alarms when an earthquake and wait for fire and as soon as possible.
\end{abstract}

Keywords: Mikrokontroler arduino, Smart phone, Smart home.

\begin{abstract}
Abstrak
Dalam penelitian ini dirancang sebuah sistem kendali kelistrikan rumah maupun komponen elektronik menggunakan mikrokontroler Arduino Uno R3 yang dilengkapi dengan sensor gerak serta terkoneksi dengan modul bluetooth dan modul SIM (Subscriber Identification Module) GSM (Global System for Mobile Communications). Selain itu, prototipe smart home juga akan dilengkapi dengan sensor pendeteksi gempa, sensor api, dan sensor asap untuk mendeteksi dini adanya gempa dan pendeteksi kebakaran. Tujuan dari penelitian yaitu untuk mengetahui kinerja dari sistem smart home. Metode penelitian yang dilakukan yaitu ekperimental dengan merancang dan membuat serta menguji prototipe smart home. Pengujian dilakukan dengan menjalankan sistem untuk mengetahui kinerja dari sistem yang dibuat. Dari hasil penelitian dapat disimpulkan bahwa sistem kendali kelistrikan dan komponen elektronik yang dibuat menggunakan mikrokontroler Arduino Uno R3 dan modul Bluetooth serta modul sim GSM dapat bekerja dengan baik, sistem kelistrikan dan komponen elektronik dapat dihidupkan dan dimatikan menggunakan sim GSM dan Modul Bluetooth. Sistem keamanan menggunakan sensor gerak dan modul sim GSM dapat bekerja dengan baik, sistem dapat mengirimkan SMS (Short Message Service) pemberitahuan kepada pemilik rumah jika mendeteksi gerakan manusia. Sistem sensor pendeteksi gempa dan kebakaran pada prototipe smart home dapat bekerja dengan baik, sistem dapat menghidupkan alarm pemberitahuan ketika mendeteksi gempa dan mendeteksi adanya api serta asap.
\end{abstract}


Kata kunci: Mikrokontroler arduino, Smart phone, Smart home.

\section{Pendahuluan}

Perkembangan dunia industri pada saat ini (Revolusi industri 4.0) sudah sangat berkembang diberbagai bidang khususnya di bidang elektronika. Perkembangan teknologi di bidang elektronika ini bisa dimanfaatkan dalam pembuatan sistem otomatisasi dan pengontrolan terhadap komponen-komponen elektronika dan listrik rumah tangga. Pengendalian saklar lampu listrik maupun komponen elaktronika seperti TV, AC, dan lain-lain dalam sebuah gedung bertingkat yang dikerjakan secara manual akan membutuhkan banyak waktu dan tenaga dalam pengoperasiannya.

Untuk itu perlu dilakukan pembuatan sistem kendali kelistrikan lampu dan komponen elektronik menggunakan smart phone yang dapat menghidupkan dan mematikan lampu (listrik) maupun komponen elektronik dari jarak jauh yang terkoneksi menggunakan Modul Bluetooth dan modul SIM GSM serta mikrokontroler Arduino Uno R3.

Penggunaan modul Bluetooth yang terkoneksi dengan mikrokontroler dilakukan untuk menghidupkan maupun mematikan komponen elektronik dan lampu pada kondisi pengguna berada di dalam rumah karena terbatasnya jangkauan dari modul Bluetooth. Sedangkan modul SIM GSM digunakan untuk menghidupkan dan mematikan komponen elektronik dan lampu jika pengguna berada di luar rumah (sedang bepergian).

Selain untuk mengendalikan komponen elektronik dan kelistrikan lampu, modul SIM GSM juga dapat digunakan untuk sistem keamanan rumah menggunakan beberapa sensor salah satunya sensor gerak (sensor PIR). Pada prinsipnya sensor akan menerima input dari suatu gerakan kemudian mikrokontroler akan memproses input dari sensor dan modul SIM GSM akan mengirimkan SMS kepada nomer tujuan sebagai pemberitahuan jika ada suatu gerakan (pencuri).

Dalam penelitian ini akan dirancang sebuah sistem kendali kelistrikan rumah maupun komponen elektronik menggunakan mikrokontroler Arduino Uno R3 yang dilengkapi dengan sensor gerak serta terkoneksi dengan Modul Bluetooth dan modul sim GSM. Selain itu, prototipe smart home juga akan dilengkapi dengan sensor pendeteksi gempa, sensor api dan sensor asap untuk mendeteksi dini adanya gempa dan pendeteksi dini adanya kebakaran. Ketika terjadi gempa atau kebakaran maka akan menghidupkan alarm untuk memberikan peringatan kepada pengguna rumah. Dan ketika terjadi kebakaran maka secara otomatis sensor akan menghidupkan alarm dan sistem pemadam kebakaran untuk memadamkan api. Tujuan dari penelitian yaitu untuk megetahui kinerja sistem kendali kelistrikan dan komponen elektronik yang dibuat menggunakan mikrokontroler Arduino Uno R3 dan Modul Bluetooth serta modul SIM GSM, mengetahui kinerja sistem keamanan yang dibuat menggunakan sensor gerak dan modul sim GSM serta sistem sensor pendeteksi gempa dan kebakaran pada prototipe smart home.

\section{Tinjauan Pustaka}

Arduino Uno adalah sebuah
rangkaian yang dikembangkan dari mikrokontroller berbasis ATmega328. Arduino Uno memiliki 14 kaki digital input/output, dimana 6 kaki digital diantaranya dapat digunakan sebagai sinyal PWM (Pulse Width Modulation). Sinyal PWM berfungsi untuk mengatur kecepatan perputaran motor. Arduino Uno memiliki 6 kaki analog input, kristal osilator dengan kecepatan jam $16 \mathrm{MHz}$, sebuah koneksi USB, sebuah konektor listrik, sebuah kaki header dari ICSP, dan sebuah tombol reset yang berfungsi untuk mengulang program [1]. 
Kelebihan Arduino diantaranya adalah tidak perlu perangkat chip programmer karena di dalamnya sudah ada bootloader yang akan menangani upload program dari komputer, arduino sudah memiliki sarana komunikasi USB, sehingga pengguna laptop yang tidak memiliki port serial/RS323 bisa menggunakannya. Bahasa pemrograman relatif mudah karena software arduino dilengkapi dengan kumpulan library yang cukup lengkap, dan arduino memiliki modul siap pakai (shield) yang bisa ditancapkan pada board arduino. Misalnya shield GPS, Ethernet, SD Card, dll [2].

Android adalah platform open source yang komprehensif dan dirancang untuk mobile devices. Dikatakan komprehensif karena Android menyediakan semua tools dan frameworks yang lengkap untuk pengembangan aplikasi pada suatu mobile device. Sistem Android menggunakan database untuk menyimpan informasi penting yang diperlukan agar tetap tersimpan meskipun device dimatikan. Untuk melakukan penyimpanan data pada database, sistem Android menggunakan SQLite yang merupakan suatu open source database yang cukup stabil dan banyak digunakan pada banyak device berukuran kecil [3].

Bluetooth merupakan sebuah teknologi komunikasi wireless yang beroperasi pada pita frekuensi 2,4 - 2,83 GHz unlicensed ISM (Industrial, Scientific and Medical). Bluetooth mampu menyediakan layanan komunikasi data antara host-host Bluetooth dengan jarak jangkauan layanan yang terbatas [4].

Relay berfungsi sebagai sakelar yang dapat bekerja berdasarkan input yang dimilikinya. Relay merupakan sakelar atau switch yang bisa dioperasikan secara listrik karena relay ini merupakan komponen electromagnet (coil) dan mekanikal (satu unit switch). Pada dasarnya relay ini menggunakan prinsip eektromagnetik untuk dapat menghantarkan aliran listrik [5].
Pada prinsipnya, SMS Gateway adalah sebuah perangkat lunak yang menggunakan bantuan komputer dan memanfaatkan teknologi seluler yang diintegrasikan guna mendistnbusikan pesan-pesan yang di generate lewat sistem informasi melalui media SMS yang dihandle oleh jaringan seluler. Modul GSM SIM 800L ini merupakan modul GSM yang dapat untuk project mikrokontroler seperti monitoring lewat SMS, menyalakan atau kontrol nyala listrik lewat SMS [6].

Buzzer adalah sebuah komponen elektronika yang berfungsi untuk mengubah getaran listrik menjadi getaran suara. Pada dasarnya prinsip kerja buzzer hampir sama dengan loud speaker, jadi buzzer juga terdiri dari kumparan yang terpasang pada diafragma dan kemudian kumparan tersebut dialiri arus sehingga menjadi elektromagnet, kumparan tadi akan tertarik ke dalam atau keluar, tergantung dari arah arus dan polaritas magnetnya, karena kumparan dipasang pada diafragma maka setiap gerakan kumparan akan menggerakkan diafragma secara bolakbalik sehingga membuat udara bergetar yang akan menghasilkan suara. Buzzer biasa digunakan sebagai indikator bahwa proses telah selesai atau terjadi suatu kesalahan pada sebuah alat (alarm) [7].

Salah satu kelebihan penggunaan sensor gerak sebagai alarm karena perangkat ini dapat mendeteksi ketika ada objek yang bergerak, seperti orang yang berjalan. Biasanya perangkat ini terintegrasi dengan perangkat lain seperti mikrokontroler arduino untuk membunyikan alarm atau memberikan notifikasi seperti sms melalui smart phone saat mendeteksi gerakan pada wilayah yang menjadi pantauannya. Penggunaan sensor gerak sebagai bagian dari sistem alarm dapat memberikan perlindungan atau peringatan tambahan karena sifatnya yang terus berfungsi selama terhubung ke sumber daya baik listrik rumah maupun baterai.

Penggunaan sensor gerak sebagai sensor lampu dan komponen elektronik, 
perangkat ini berfungsi sebagai saklar otomatis yang dapat menyalakan atau mematikan lampu saat mendeteksi adanya gerakan atau tidak ada gerakan di ruangan. Penggunaan sensor lampu menggunakan sensor gerak dapat menghemat penggunaan listrik terutama pada daerah yang cukup jarang dilalui orang.

Sensor getaran merupakan suatu alat yang digunakan untuk mendeteksi adanya getaran dan kemudian getaran tersebut akan diubah dalam ke dalam sinyal listrik. Sensor getaran disebut juga cassing measurement. Sensor yang digunakan adalah sensor seismic transduser, yaitu sensor yang digunakan untuk mengukur kecepatan dan percepatan. Sensor getaran juga dapat digunakan untuk mendeteksi adanya gempa.

Flame sensor atau sensor api merupakan sensor yang mempunyai fungsi sebagai pendeteksi nyala api yang dimana api tersebut memiliki panjang gelombang antara $760 \mathrm{~nm}-1100 \mathrm{~nm}$. Sensor api menggunakan infrared sebagai tranduser dalam mensensing kondisi nyala api. Cara kerja Flame sensor atau sensor api yaitu dengan mengidentifikasi atau mendeteksi nyala api dengan menggunakan metode optik. Pada Flame sensor atau sensor api menggunakan tranduser yang berupa infrared (IR) sebagai sensing sensor. Tranduser ini digunakan untuk mendeteksi akan penyerapan cahaya pada panjang gelombang tertentu. Yang dimana memungkinkan Flame sensor atau sensor api untuk membedakan antara spectrum cahaya pada api dengan spectrum cahaya lainnya seperti spectrum cahaya lampu.

Sensor Asap MQ2 merupakan sensor yang dapat digunakan sebagai sensor deteksi Alkohol, H2, LPG, CH4, CO, Asap, dan Propane. Sensor asap atau sensor gas sangat cocok digunakan untuk alat emergensi sebagai deteksi gas-gas, seperti deteksi kebocoran gas, deteksi asap untuk pencegahan kebakaran dan lain lain.

Modul SIM 900 GSM/GPRS adalah bagian yang berfungsi untuk komunikasi antara mikrokontroller. Modul ini mendukung komunikasi dual band pada frekuensi 900/1800 MHz (GSM 900 dan GSM 1800) sehingga fleksibel untuk digunakan bersama kartu SIM dari berbagai operator di Indonesia. Modul GSM SIM 900 ini juga disertakan antena GSM yang kompatibel.

Sensor cahaya adalah Photodioda yang bekerja berdasarkan intensitas cahaya. Jika photodioda terkena cahaya maka photodioda bekerja seperti dioda pada umumnya, tetapi jika tidak mendapat cahaya maka photodioda akan berperan seperti resistor dengan nilai tahanan yang besar sehingga arus listrik tidak dapat mengalir. Isi bagian tinjauan pustaka ditulis ringkas, dan hanya teori yang benar-benar digunakan sebagai dasar penelitian.

\section{Metode Penelitian}

Lokasi penelitian dilakukan di Laboratorium Teknik Mesin Universitas Muhammadiyah Metro. Penelitian ini dilakukan dengan metode eksperimen nyata (true experimental research) dengan melakukan perancangan dan pembuatan serta pengujian prototipe smart home berbasis mikrokontroler arduino dan smart phone. Pengujian dilakukan dengan menjalankan sistem untuk mengetahui kinerja dari sistem yang dibuat.

$$
\text { Rancangan sistem kendali }
$$

kelistrikan rumah menggunakan mikrokontroler arduino dan modul Bluetooth dijelaskan seperti pada Gambar 1 .

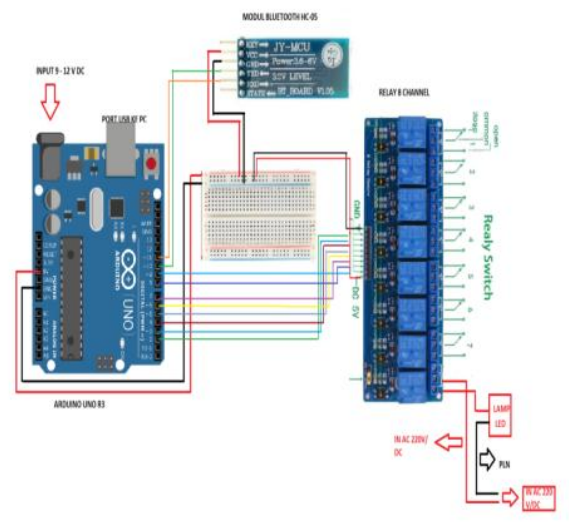

Gambar 1. Rancangan sistem Bluetooth 
Rancangan sistem kendali kelistrikan rumah dan sistem keamanan rumah menggunakan mikrokontroler arduino dan modul GSM (SIM 900 A) dijelaskan seperti pada Gambar 2.

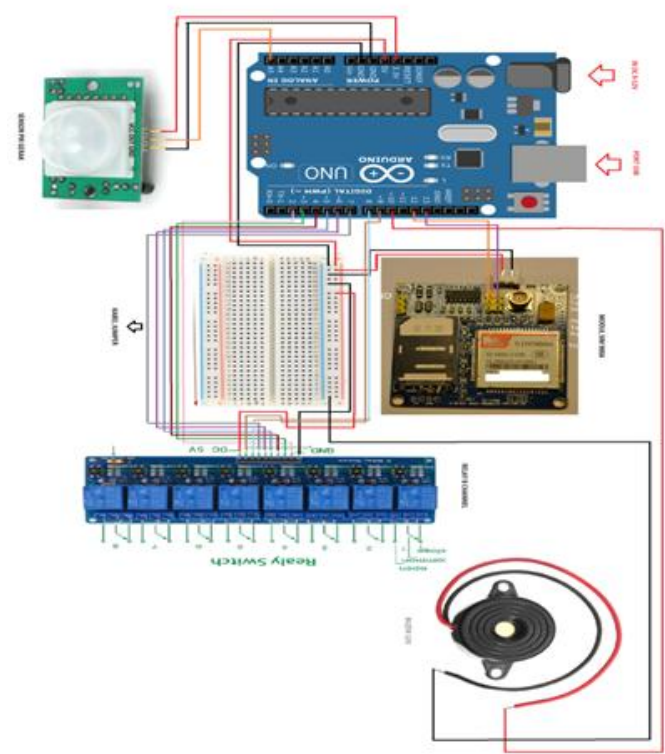

Gambar 2. Rancangan sistem sim GSM

\section{Hasil dan Pembahasan}

Dari hasil penelitian yang telah dilakukan diperoleh miniatur rumah (smart home) dengan sistem kelistrikan dan pengaman rumah menggunakan smart phone (android) serta pengaman rumah menggunakan sensor getaran, sensor api dan sensor gas (asap) yaitu sebagai berikut.

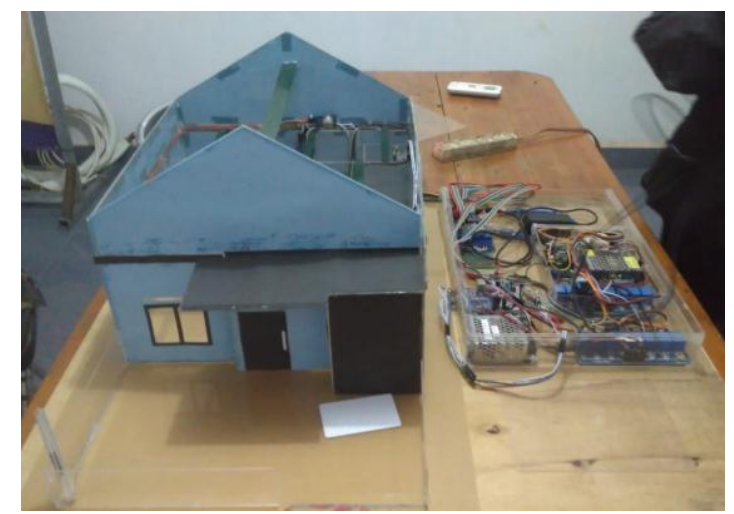

Gambar 31. Hasil pembuatan Rangkaian sistem Smart home

Proses pengujian kinerja sistem smart home yang dibuat dilakukan dengan menjalankan sistem kemudian memberikan simulasi sesuai dengan sensor yang akan diuji. Pengujian dilakukan untuk mengetahui kinerja sistem yang dibuat dapat bekerja sesuai dengan yang diharapkan atau tidak. Adapun hasil pengujian dijelaskan seperti pada tabel berikut.

Tabel 1. Hasil pengujian

\begin{tabular}{|c|c|c|c|}
\hline \multirow{2}{*}{ No. } & \multirow{2}{*}{ Jenis Sistem } & \multicolumn{2}{|c|}{ Kinerja Sistem } \\
\hline & & Bekerja & Tidak \\
\hline 1 & Bluetooth & $\checkmark$ & \\
\hline 2 & SIM900A & $\checkmark$ & \\
\hline 3 & Sensor Gas (asap) & $\checkmark$ & \\
\hline 4 & Sensor Api & $\checkmark$ & \\
\hline 5 & Sensor Gerak & $\checkmark$ & \\
\hline 6 & Sensor Getaran & $\checkmark$ & \\
\hline
\end{tabular}

Dari hasil pembuatan miniatur smart home dengan sistem kelistrikan menggunakan modul Bluetooth yang telah dilakukan dan proses pengujian diperoleh hasil sebagai berikut.

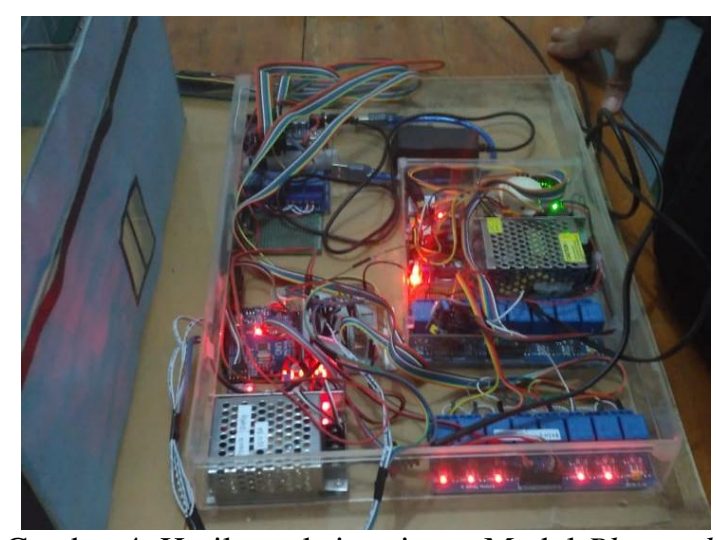

Gambar 4. Hasil rangkaian sistem Modul Bluetooth

Berdasarkan hasil pengujian kinerja sistem kelistrikan menggunakan modul Bluetooth diketahui bahwa sistem yang dibuat dapat bekerja dengan baik, hal ini terbukti dengan sistem kelistrikan rumah (lampu dan peralatan lainnya) dapat dihidupkan dan dimatikan menggunakan smart phone (android) yang sudah terinstal aplikasi Bluetooth controller. Dengan sistem ini dapat mempermudah dalam menghidupkan dan mematikan komponen listrik seperti lampu dan lain-lain tanpa harus mematikan melalui saklar listrik. Modul Bluetooth yang dibuat memiliki jangkauan terhubung dengan smart phone (android) yang cukup baik, hal ini terbukti jangkauan terhubung antara modul 
Bluetooth dan android mencapai lebih dari $30 \mathrm{~m}$.

Sistem kendali kelistrikan dan pengaman menggunakan modul SIM900A dan sensor gerak dibuat untuk menghidupkan sistem kelistrikan rumah seperti lampu, AC dan komponen listrik lainnya melaui SMS dengan kode tertentu sesuai dengan program yang di-upload ke dalam mikrokontroler arduino. Selain itu sistem ini juga dibuat untuk sistem pengaman rumah yang prinsip kerja dari sistem yang dibuat yaitu untuk memberikan informasi kepada pemilik rumah melalui SMS apabila di dalam rumah terdapat suatu pergerakan manusia (pencuri). Berdasarkan hasil pengujian dapat diketahui bahwa sistem yang dibuat dapat bekerja dengan baik. Hal ini terbukti dengan sistem kelistrikan rumah dapat dihidupkan dan dimatikan melaui SMS. Selain itu sistem juga dapat mengirimkan SMS jika di dalam rumah terdapat pergerakan manusia. Sistem ini memliki kelebihan yaitu jangkauan yang lebih jauh dibandingkan dengan modul Bluetooth.

Sistem kendali kelistrikan dan pengaman rumah dibuat menggunakan modul SIM GSM sehingga kinerja sistem tersebut akan dipengaruhi oleh signal yang diterima oleh SIM yang digunakan. Ketika kondisi signal baik maka sistem akan bekerja dengan maksimal, namun jika signal dalam kondisi kuarang baik maka sistem juga akan bekerja kurang maksimal. Selain itu, sistem juga perlu dihidupkan dan dimatikan secara manual, sehingga perlu dikembangkan sistem yang secara otomatis dapat bekerja tanpa harus menghidupkan dan mematikan sistem secara manual.

Sistem

pengaman

rumah

menggunakan sensor api, sensor getaran dan sensor asap dibuat untuk mendeteksi gempa dan kebakaran. Proses pembuatan menggunakan rangkaian dengan relay listrik sederhana tanpa menggunakan mikrokontroler arduino. Sistem pengaman yang dibuat hanya untuk menghidupkan alarm ketika terjadi bencana alam seperti gempa dan kebakaran. Dengan alarm tersebut diharapkan dapat memberikan informasi kepada pemilik rumah sehingga dapat meminimalisir dampak yang diakibatkan oleh bencana tersebut. Berdasarkan hasil pengujian dapat diketahui bahwa sistem dapat bekerja dengan baik. Hal ini terbukti dengan alarm yang dapat hidup ketika terdapat api atau asap serta geratan. Namun hasil pengujian untuk sensor getaran sistem yang dihasilkan kurang maksimal, hal ini disebabkan oleh sensitivitas sensor yang sulit untuk disesuaikan dengan kondisi geratan yang terjadi. Selain itu secara keseluruhan sistem yang dibuat perlu dimaksimalkan dalam penyampaian informasi kepada penghuni rumah ketika berada di luar rumah melalui SMS. Untuk itu perlu dikembangkan sistem pengaman rumah menggunakan sensor api dan asap.

\section{Kesimpulan}

Dari hasil penelitian dapat disimpulkan bahwa sistem kendali kelistrikan dan komponen elektronik yang dibuat menggunakan mikrokontroler Arduino Uno R3 dan modul Bluetooth serta modul SIM GSM dapat bekerja dengan baik. Sistem kelistrikan dan komponen elektronik dapat dihidupkan dan dimatikan menggunakan SIM GSM dan Modul Bluetooth. Sistem keamanan menggunakan sensor gerak dan modul SIM GSM dapat bekerja dengan baik. Sistem dapat mengirimkan SMS pemberitahuan kepada pemilik rumah jika mendeteksi gerakan manusia. Sistem sensor pendeteksi gempa dan kebakaran pada prototipe smart home dapat bekerja dengan baik. Sistem dapat menghidupkan alarm pemberitahuan ketika mendeteksi gempa dan mendeteksi adanya api atau asap.

\section{Referensi}

[1] Magdalena, G., Aribowo, A., dan Halim, F. (2013): Perancangan Sistem Akses Pintu Garasi Otomatis. Proceedings Conference on Smart- 
Green Technology in Electrical and Information System, 301-205.

[2] Wibowo, H., Somantri, Y., dan Haritman, E. (2013), Rancang Bangun Magnetic Door Lock Menggunakan Keypad Dan Solenoid Berbasis Mikrokontroler Arduino Uno, Jurnal Electrans, 12, 39-48.

[3] Setiawan, Iwan., Andjarwirawan, Justinus dan Handojo, Andreas. (2013), Aplikasi Makassar Tourism Pada Kota Makassar Berbasis Android, Jurnal Infra, 1, 156.

[4] Potts, J., dan Sukittanon, S. (2012). : Exploiting Bluetooth on Android Mobile Devices for Home Security Application. Proceedings of IEEE, University of Tennessee at Martin, USA.

[5] Santoso, H. (2013). Pengertian, Fungsi, Prinsip, dan Cara Kerja Relay.

[6] Mulyono, Sri (2011), Rancang Bangun Sistem Kontrol Keamanan Mobil Jarak-Jauh Via SMS Melalui Jaringan GSM Berbasis Mikrokontroller ATmega32.

[7] Rahardjo, R. F. A. (2012). Pendeteksi Ketinggian Level Air Dengan Tampilan Led Berbasis Mikrokontroller Atmega 8 Serta Led Buzzer Dan Seven Segment Sebagai Peringatan Dini Kenaikan Air Pasang (Rob) Berbasis Programmable Logic Controller Cp1e-E40dr-A, 17(1). 